\title{
Neglected Appendicitis? One Patient Two Diagnosis? Differential Diagnosis of Acute Abdominal Pain
}

\section{Apendicite Aguda Negligenciada? Um Paciente, Dois Diagnósticos? Diagnóstico Diferencial de Abdómen Agudo}

Eunice Vieira e Monteiro ${ }^{1}$, Cláudia Paiva² Paulo Soares $^{3}$

Corresponding Author/Autor Correspondente:

\begin{abstract}
Authors present a case report of a female patient, with 38-years-old, admitted with alithiasic acute pancreatitis. During the hospitalization on day 6 she referred migration of the pain to the lower right quadrant and had pain in decompression; she underwent a computed tomography scan that was compatible with acute appendicitis.

She was admitted to the operating room and laparoscopic appendectomy was performed. Surgery and hospitalization were uneventful and she was discharged on the $10^{\text {th }}$ day after admission.

The purpose to present this case is related to need to draw doctors' attention to do an accurate physical examination and a selective interpretation of diagnostic exams in order to make a correct differential diagnosis and guide treatment.

KEYWORDS: Abdominal Pain; Appendicitis/diagnosis; Pancreatitis
\end{abstract}

\footnotetext{
1. Surgery Resident, General Surgery Service, Centro Hospitalar Universitário do Porto, Porto, Portugal. 2. Assistant at Extra-Digestive Unit and Breast Pathology Unit, General Surgery Service, Centro Hospitalar Universitário do Porto, Porto, Portugal. 3. Graduated Assistant at Hepatobiliopancreatic Unit, General Surgery Service. Program of Pancreas Transplantion. Program of Liver Transplantation. Centro Hospitalar Universitário do Porto, Porto, Portugal. 


\section{RESUMO}

Os autores apresentam o caso clínico de uma paciente do género feminino, de 38 anos de idade, admitida por pancreatite aguda alitiásica.

No sexto dia de internamento, a doente refere migração da dor para o quadrante inferior direito e apresentava dor à descompressão; realizou uma tomografia computorizada que foi compatível com apendicite aguda.

Foi admitida no bloco operatório e foi submetida a apendicectomia laparoscópica. A cirurgia e o internamento decorreram sem intercorrências e a doente teve alta hospitalar ao décimo dia de internamento.

O propósito da apresentação deste caso prende-se com a necessidade de chamar a atenção dos médicos para a importância da realização de um exame físico acurado e de uma interpretação seletiva dos exames de diagnóstico de forma a realizar um diagnóstico diferencial correto e orientar o tratamento.

PALAVRAS-CHAVE: Apendicite/diagnóstico; Dor Abdominal; Pancreatite

\section{INTRODUCTION}

Authors present a case of acute appendicitis in a patient hospitalized with alithiasic acute pancreatitis. ${ }^{1}$

The purpose to present this case is to point out the necessity of a complete clinical history, abdominal physical examination and selected complementary diagnostic exams to make a correct diagnosis as long as there are a lot of differential diagnoses of acute abdomen.

Once the diagnosis is established, a correct treatment regimen can be individualized to the patient.

\section{CASE REPORT}

Female patient, 38-years-old, admitted on the Emergency Department due to epigastric abdominal pain with 24 hours of evolution.

She had no fever, no nausea, no anorexia, no vomiting, no irradiation neither worsen or relief factors. No alcohol consumption nor medication.

Objectively, she was hemodynamically stable, apyretic, with abdominal tenderness on palpation of the epigastrium.

At admission, laboratory tests showed only elevation of pancreatic enzymes: amylase of $928 \mathrm{U} / \mathrm{L}$ (Normal range (NR) 0-53 U/L) and lipase of $1475 \mathrm{U} / \mathrm{L}$ (NR 30-190U/L).

She underwent an ultrasound that showed non-ectatic bile ducts; normodistended gallbladder without parietal thickening or vesicular lithiasis; normal pancreas and spleen; no parietal thickening of the loops visualized. Ileocecal appendix not observed; no peritoneal effusion.

The diagnosis of alithiasic acute pancreatitis was assumed and the patient was hospitalized under conservative treatment.
On day 3 of admission, laboratory tests showed normalization of pancreatic enzimes (amylase $58 \mathrm{U} / \mathrm{L}$ e lipase $68 \mathrm{U} / \mathrm{L})$.

Patient referred migration of the pain to the lower right quadrant during hospitalization and on day 6 of admission there were present peritoneal findings on palpation (pain in decompression). Computed tomography scan (CT) was performed to exclude other etiology than lithiasis or complication of pancreatitis.

CT scan revealed splenoportal axis with normal caliber, absence of ectasia of the intrahepatic biliary tree and normal caliber of the main bile duct; normodistended gallbladder, without vesicular lithiasis; pancreas of conserved morphology and density without dilation of the Wirsung; no evidence of peripancreatic collections; ileocecal appendix with enlarged caliber and enhanced walls and a bulky fecalite inside; small amount of free liquid in the pelvis (Fig. 1).

She was proposed to laparoscopic appendectomy, which was uneventful and was discharged on the $10^{\text {th }}$ day after admission.

\section{DISCUSSION/CONCLUSION}

Acute abdominal pain is a frequent symptom in the Emergency Surgery Department and can be caused by various pathologic processes. ${ }^{1,2}$

After evaluation of the patient with abdominal pain the diagnosis may not be clear in up to $30-40 \%$, particularly in women. ${ }^{1}$

The diagnosis of acute pancreatitis (AP) requires the presence of two of the following criteria: acute onset of persistent, severe, epigastric pain often radiating to the back, elevation in serum lipase or amylase to three times 
upper limit of reference and characteristic findings of acute pancreatitis on imaging.

Our patient did not have irradiation of the pain neither an image compatible with acute pancreatitis. ${ }^{1}$

After reviewing the literature, it is known that elevated serum amylase and lipase levels can be observed in several medical conditions, but the highest values are usually associated with acute or acute in chronic pancreatitis and gallbladder diseases; however extra-pancreatic causes of acute abdominal pain may be implicated in the raise of serum pancreatic enzymes but the levels rarely reach the range we are used to see in the setting of acute pancreatitis. ${ }^{1}$

As we know lipase increases within 4 hours after the onset of symptoms, peaks at 24 hours, and decreases over 14 days. $^{3}$

Amylase increases by 6 hours after the onset of symptoms, peaks later at 48 hours and decreases over 7 days until it reaches the normal range. ${ }^{3}$

Lipase half-life in plasma is longer than the half-life of amylase and as a result its activity remains increased longer than that of amylase.,

Serum lipase is more valuable in the diagnosis of acute pancreatitis but it is not specific either. Serum lipase elevation greater than three times upper level of reference (ULR) has been reported in patients with renal insufficiency, malignant tumors, cholecystitis and esophagitis.

In patients with appendicitis serum lipase can also rise but there are no reports of elevations three times above ULR. ${ }^{5}$

In a series of patients with appendicitis (149 cases), moderate values of amylase were found in 38\%, the highest recorded was $533 \mathrm{U} / \mathrm{L}$ in a patient with obstructed gangrenous appendix. ${ }^{4,6}$ In another series (44 cases) of patient with appendicitis, only $4.5 \%$ had amylase levels 1.3-1.9 above ULR. ${ }^{2}$ However it is important to notice that in up to about $35 \%$ of cases of acute appendicitis amylase levels are less than 2 times ULR. Some authors believe the amylase level is related to peritonitis, with higher levels in case of appendix perforation. ${ }^{2,7}$

In this patient pancreatic enzymes returned to levels of reference on day 3 after admission which may put in cause the initial diagnosis of acute pancreatitis.

As the clinical picture changed during the hospitalization surgeons made a CT scan. ${ }^{3-5,8,9}$

There are rare reports described in the literature of appendicitis as a complication of mild pancreatitis; however, in the CT there were signs of appendicitis and no signs of pancreatitis which excludes this possibility. ${ }^{5}$

Although the diagnosis of appendicitis is mainly clinic it is important to use complementary exams if the clinic is not very clear.

In the literature and regarding appendicitis, there are reports of ultrasound sensivity and specificity of $86 \%$ and $81 \%$, respectively and CT sensivity and specificity of $94 \%$ and $95 \%$, respectively.

In our case, doctors assumed acute pancreatitis even in the absence of a history of alcohol consumption (35\% of cases of AP) or evidence of lithiasis ( $40 \%$ of cases of AP) in the ultrasound and CT, which are the main causes of acute pancreatitis. ${ }^{10}$ Less frequent causes of AP where also excluded.

To our knowledge this is the first reported case in adults of elevated amylase and lipase this high in a patient with appendicitis and a radiographically and intra-operative normal pancreas. ${ }^{1-11}$

This leaves us to think if the acute pancreatitis was treated with conservative management and appendicitis a new diagnosis? Appendicitis was only diagnosed on $6^{\text {th }}$ day based on migration of the pain and CT results.

If the primary diagnosis was appendicitis it was expected for the patient to had more symptoms and the appendix to be perforated at the time of the surgery which did not happen. ${ }^{5}$

Furthermore and retrospectively the patient should have made a CT scan earlier in the course of the disease to confirm acute pancreatitis and exclude other causes of abdominal pain such as appendicitis that make differential diagnosis with pancreatitis. ${ }^{10}$ Other diseases that may mimic acute pancreatitis are causes of acute epigastric pain such as peptic ulcer disease, choledocholithiasis cholecystitis or cholangitis, perforated viscus, intestinal obstruction, mesenteric ischemia or hepatitis for instance.

The above case was initially diagnosed as an alithiasic acute pancreatitis based solely on the report of the pain and elevation of pancreatic enzymes with no signs of pancreatitis on the ultrasound.

The migration of the pain and $\mathrm{CT}$ scan results led to the diagnosis of an acute appendicitis and thus the team decided to proceed with laparoscopic appendectomy: the operative specimen confirmed the diagnosis of acute appendicitis. $^{8}$ 


\section{ETHICAL DISCLOSURES}

CONFLICTS OF INTEREST: The authors have no conflicts of interest to declare.

FINANCING SUPPORT: This work has not received any contribution, grant or scholarship.

CONFIDENTIALITY OF DATA: The authors declare that they have followed the protocols of their work center on the publication of data from patients.

PATIENT CONSENT: Consent for publication was obtained.

PROVENANCE AND PEER REVIEW: Not commissioned; externally peer reviewed.

\section{RESPONSABILIDADES ÉTICAS}

CONFLITOS DE INTERESSE: Os autores declaram a inexistência de conflitos de interesse na realização do presente trabalho.

FONTES DE FINANCIAMENTO: Não existiram fontes externas de financiamento para a realização deste artigo.

CONFIDENCIALIDADE DOS DADOS: Os autores declaram ter seguido os protocolos da sua instituição acerca da publicação dos dados de doentes.

CONSENTIMENTO: Consentimento do doente para publicação obtido.

PROVENIÊNCIA E REVISÃO POR PARES: Não comissionado; revisão externa por pares.

\section{REFERENCES}

1. Hawramy TA, Mohammed DA. Serum Amylase Level Measurement in Acute Abdominal Pain. Kurdistan J Appl Res. 2019;4(Special Issue).

2. Cust R, Marques LC. Validade da amilasemia e da lipasemia no diagnóstico diferencial entre pancreatite aguda/crónica agudizada e outras causas de dor abdominal. Arq Gastroenterol. 2003;4:233-8.

3. Jasdanwala S, Babyatsky M. A critical evaluation of serum lipase and amylase as diagnostic tests for acute pancreatitis. Integr Mol Med. 2015;2:189-95.

4. Ismail OZ, Bhayana V. Lipase or amylase for the diagnosis of acute pancreatitis? Clin Biochem. 2017;50:1275-80.

5. Nozari N. Appendicitis as a complication of acute pancreatitis; A case report. Govaresh. 2016;21:200-2.

6. Bolam RF. Serum Amylase and Acute Abdominal Disease. Br Med J. 1955;2:1086.

7. Omid Amanollahi ST. The study of diagnostic value of elevation of serum amylase as a predictive factor for appendiceal perforation in children with acute appendicitis. Int J Pediatr. 2018;6:7213-7.

8. Agrawal VP, Wasnik N, Kunal R, Khatri V. Acute pancreatitis Masquerading as acute appendicitis - A diagnostic dilemma. Int J Biomed Adv Res. 2013;666-8.
9. Lankisch PG, Apte M, Banks PA. Acute pancreatitis. Lancet. 2015;386:85-96.

10. Sutar SS. Severe acute pancreatitis presenting as appendicular perforation an unusual presentation. J Med Sci Clin Res. 2016;04:10085-8.

11. McAninch SA, Essenburg A. Pediatric subhepatic appendicitis with elevated lipase. Am J Emerg Med. 2019;37:174.e1-174. e3. 